\title{
The Contractual Freedom as an Essential Condition for the Existence of the Contract in a Global Economy
}

\author{
Irena Lavdari PhD Candidate
}

\author{
The European University of Tirana \\ Faculty of Law \\ ilavdari@yahoo.com
}

\section{Doi:10.5901/mjss.2013.v4n11p429}

\section{Abstract}

"The idea of the contract as a sheer and complete subjective will which appears without individual barriers and without restrictions that derive from objective, factual, or legal conditions, is an abstract idea that cannot be reflected in the reality we live." The contractual freedom makes possible the maximal development of the economic relations based on free and voluntary cooperation between the interested parties. "The private economic initiative is free, but cannot happen if it harms the common interest or damages the safety, freedom or human dignity". In conformity with the article 660 of the Civil Code "The parties can freely define the content of the Contract by respecting the restrictions provided by the current legislation". For the contract to be valid according to the article 663 of the Civil Code there must exist the reciprocal agreement between the contractual parties which is an essential condition for its existence. The content of the autonomy of the will is not limited only in the ability of the parties to make contractual agreement but more specifically to allow the parties to decide about the rules of signing of the contract on their own. But, is it possible to discuss the contractual freedom more practically only because two or more parties, without any influence from outside sources, agree to improve some of their interests? Nowadays, the private autonomy is more limited than in the past. The development of a modern globalised economy, has had an influence upon the traditional idea of the contract which is understood as a "converge of purpose between the parties". The economy has generated the massive standardization of the goods and services in the marketplace by defining the depersonalizing process of the individual contracts, by affecting the text of the contract, where in most of the cases there is no individual negotiation among the parties but the contract is one-sidedly prepared by the company and the consummers accept it as it is, without being able to affect by their will in its content.

Keywords: Contract, the will of the parties, contractual freedom, legal condition, globalization

\section{The Importance of the Contractual Freedom}

The contractual freedom has a special importance for the contractual right and it is its basic principle (Dauti,2010, p.59). This kind of freedom is considered indispensable for making the contracts in general, which appear in the economic activity for the circulations of goods and the offering of services. Concretely, the contractual freedom means that the legal system offers the opportunity to the contractual parties, by evaluating their interests under the circumstances specified by law, to define the legal regime of the contracts to be signed as well as the kind of rights and obligations that will derive from this for the parties. Typical for the right of obligations is the method of regulating the property relations in conformity with the will of the contractual parties that participate in such relations. The Albanian Civil Legislation specifies the rules by which the relations are regulated, only in those cases when the contractual parties have not decided on something else.

The contractual freedom offers the opportunity for the participants to regulate the relations of obligations among them by their free will. More concretely, the contractual freedom means that every subject of the right can freely decide to sign the specified contract or not, to freely choose the person with whom will make the contract, to freely define the content of the contract, its form and the way of its signing as well as to freely decide about the change and annulment of the contract. Seen in the historic perspective, the 20-th century is the century in which the contract triumphs (Zweigert K. \& Kötz H., 3-rd edition, 1998). The contractual freedom guarantees that the contract signed by the parties has the power of law above them. It is important to emphasize that the contractual freedom and the autonomy of the will of the contractual parties are among the main and the most significant principles of the right of obligations. Each contract has to do with the reasonable support of those interests that are expected to be achieved by the parties and there is no reason to define by law punishing conditions when none of the parties has demanded something like this on purpose. (From 
Freedom of Contract to Forcing Parties to Agreement. On the consequences of Breaking off Negotiations in different Legal Systems, 12, lus gentium, Journal of the University of Baltimore Center for International and Comparative Law 2006)

In general, the contractual freedom implies the authorization of the subjects of right that in support of their will, can create contractual relations, perform legal actions by which to define the way, form as well as their content. However, contractual parties are free to decide with whom to make the particular contract, which is going to be the object and its content. Despite this fact, the contractual freedom must be in conformity with the legal regulations that have imperative, constitutional nature and are suitable to the morality of a society. The contractual freedom is a consequence of the operation of law of the market. The independence of the commercial companies is expressed in the fact that these companies have the opportunity to freely trade their products. These products can be launched, sold or bought in the market, the services of different kind can be provided as well as a series of legal activities can be performed which are related to the circulation of the goods and the provision of the services. All these actions of the commercial companies are executed by means of the contract, which is the most common legal instrument by which the rights and obligations for the parties are created, but as usually this happens only when they were expressed for these rights and obligations in their free will. The contract, being an instrument of this kind, makes possible not only the inner circulation but also the international one. (Dauti Nerxhivane, Some important issues related to the contractual freedom, Justitia, no.1, legal scientific periodical of the Faculty of Law, 2008)

\section{The Contractual Freedom According to the Albanian Legislation}

The contract is the most important means that harmonizes the economical, commercial, and legal interests among the parties. All the material and cultural demands of the society as well as those of the individuals are intended to be met due to the contract. The Albanian Civil Code regulates the most important contracts as well as those that are commonly faced in real life or in the civil circulation such as the selling, the renting, the contract of enterprise, the insurance contracts etcetera. Our contractual right does not recognise the principle "numerous ciazus" the so-called the principle of the permitted contracts. According to this principle, the parties in the civil circulation have the right to make only those contracts that are provided by law. In addition, our practice and legal doctrine about the contractual right goes further on because it allows the signing of contracts and agreements not provided by law as long as their content is not in contradiction with the provisions of the general part of the Civil Code and with those of the obligations and the general principles of the right (Semini, 2010, p.11).

The contractual freedom is a relatively new principle even for the Albanian right. The definition of the contract is provided in the article 659 of the Albanian Civil Code, which declares that: "The contract is the legal act by which one or some parties establish, change, or annul a legal relation".( The Civil Code of the Republic of Albania, approved by law No. 7850 date 29.07.1994, changed by law No. 8536, date 18.10.1999 and No. 878, date 3.5.2001). As far as the contract of sale is concerned, the Albanian Civil code provides in the article 660 that "The parties in the contract define freely its content, within the limits specified by the legislation in power." In the same way, related to this issue the article 676 of the Civil Code, ratifies that "The contract is considered signed when both parties have given their mutual consent by agreeing for each essential condition stated in the contract". The demonstration of the will can be clearly expressed or approved in silence".

For the existance of the contract it is necessary the existance of the mutual consent between the parties. Such an important principle is provided in the first paragraph of the article 663 of the Albanian Civil Code which states one of the essential conditions for the signing of the contract based on the mutual consent of the parties involved. The Albanian author Mariana Semini treats the autonomy of the will in her book " The right of the obligations and contracts", in three main directions.

The first philosophical direction is based on the Russo's point of view, according to whom the man is free from nature and as such must be free to establish every legal relation. The supporters of this point of view accept the so-called social contract. The Albanian Civil Code has accepted and ratified for the first time in its provisions the theory of the free contractual will along with its three directions. The article 660 of the Albanian Civil Code in power which is mentioned above expresses the right essence of the theory of the contractual will and the first direction, its philosophical direction.

The second direction of this theory is the moral direction, according to which every contract must meet the condition: "where there's a contract, there's justice". The contract must be in the interest of both parties, because both parties have to build a kind of relation to one another in order to achieve something that would be beneficial for them. As far as this is concerned the article 422 of the Albanian Civil Code states that: "the creditor and debtor must behave 
correctly to one another, must be impartial and based on common sense".

The third direction related to the autonomy of the contractual will is the economic direction, according to which the autonomy of the will must be in conformity with the achievement of the economic interest, being these material or not material of the contractual parties. In other words, these interests must be accompanied with the increase of the quantity of the production, the raise of price, the reduction of the cost, release from the competition etc. The economic direction is ratified in the article 421 of the Albanian Civil Code which states the economic nature of the duty. This provision sanctions that "The object of obligation must have an economic evaluation and must answer the material or not material interests of the creditor".

The display of the contractual will is truly free when these three directions are realized at the same time. If parties had not been free in their display of the will to sign the contract, then it would not be valid. The approval taken by use of force, under the conditions of deceipt, threat, mental disorder or in the great economic need has no legal consequences, because the contract is not valid (Articles 94-99 of the Civil Code). As far as the effect of the the contract for the parties is concerned, the article 690 of the Albanian Civil Code provides that "The contract signed legally has the power of law towards the parties. It may be annuled or changed by the mutual consent of the parties or due to the causes provided by law."

\section{The Restriction of the Contractual Right}

The contractual freedom for the subjects of right is not unlimited. It is restricted by the viewpoint of the opportunity of choice by the contractual parties, the viewpoint of the content of the contract, by means of the contracts of adhesion, in the formular contracts by means of form of contracts, as well as in cases when for the signing of the contract is required the giving of the consent (Dauti Nerxhivani, Some Important Issues Related to the Contractual Freedom, Justitia, No.1 legal scientific periodical of the faculty of law, 2008). The adhesion contracts are contracts in which the conditions, the rights and obligations that derive from the contract of one of the parties, are defined. Essential standard conditions are present in their content. It is thought that these kind of contracts restrict the free will of the parties, due to the fact that they do nothing else but sign the contract. However, it cannot be said that there is any barrier in the expression of the free will because such contracts are provided for civil, legal relations that have a usual, continuous periodical nature such as the relations with the clients in the contract of sale or the contract of renting real estates, state owned property, etc. In relations of this kind, which more or less appear in the same way in the civil circulation, it is entirely in the hands of the party that will sign the contract to evaluate it and decide if it is worthy for them or not. In case they want to exclude any of the conditions, the proposal can be made to the other party that had compiled the contract and in case of discrepancy or disapproval of the proposal, to decide not to sign the contract and demand to sign another contract with another party.

Such standard contracts are provided in the legislation of France, Germany, Netherlands and of other countries but recently have appeared even in the civil area in Albania (Michel Fromont "The Greatest Foreign Systems of Right", Papirus, Tirana, 2009). The Albanian Civil Code provides the "model" contracts compiled by a powerful party in the market that has dominant position in a certain area in the articles 686 and 687 of the Civil Code. These articles use expressions such as "the contracts signed by modules or forms" which in fact are adhesion contracts. Concretely, the Albanian Civil Code in the article 686 provides that "The general conditions of the contract, prepared by one of the contractual parties, have effect upon the other party, when in the case of the termination of the contract, this one has approved or must have approved the conditions, by paying a usual attention upon them. The general conditions are rendered invalid when they cause disproportional loss or damage of the interests of the contractual parties, especialy when they change essentally from the principles of equality and impartiality expressed in the provisions that regulate contractual relations in this Code. Legal effects are not caused by those conditions that are in favour of the party that has prepared them beforehand, restrictions of responsibility, opportunity to retract from the contract, to suspend its execution, or to appoint deadlines towards the other party, or restrictions to retract from the contractual freedom, in relation to another party, the conditions of arbitration or avoidance from the competence of the judiciary organs, despite the case when they are separately approved in handwriting form from the other party".

The contracts signed in modules or form, are usually prepared by economical and financial companies that have a large number of clients. These contracts are compiled in a very explicit and racional way, which is a result of their long experience, and due to this the transaction happens faster. It is important to mention that this forms predict the numerous situations that can be caused from the establishment of the legal relations with their clients in general (Hetemi,1996, p.214). Their purpose is to accelarate and simplify the circulation of goods. The form contract are executed in our contemporary economy in the inner circulation as well as in the international one (Dauti, 2000, p.28). In 
the civil circulation of the Albanian market the standard or form contracts are mainly used by the trade companies that have almost monopolistic position in the market or that are enough powerful to dictate their conditions to the consummer party. For instance, the contracts of supply of electricity KESH (The Albanian Corporate of Energetics ), the contracts of telephone companies such as ALBTELECOM, or the contracts that offer cellular coverage services such as AMC, VODAFON, etc.

The Albanian Civil Code of 1929 provides that, if the duty of the party compared to the benefit that it gets due to the contract or compared to the benefit that the other party gets, is out of proportion in a way that it is assumed that the consent has not been completely free, the judge may annul the contract based on the request of the party concerned (The Civil Code of the year 1929, article 1029). The actual code has not provided this case but only the situation when one of the parties has been under a great need for money, something that has persuaded it to approve the juridicial act. This situation is described in the article 99 which explicitly states that "The juridicial action can be announced invalid in the case it offers the opportunity that one party, due to the great need of money, can undertake duties that compared to the benefits of the other party are negligible".

\section{The Interpretion of the Contract Related in Respect to the Contractual Freedom}

The Civil Code of 1994 has regulated for the first time the institution for the interpretation of the contract in the articles (861 - 689). During the interpretation of the contract, special attention must be paid to understand the real and common purpose of the parties without being restricted only to the meaning of the words and in order to do that, the parties attitude before and after the contract must be analysed. The principle that must lead the parties in the interpretation of the contract is good will (article 682). The conditions of the contract must be interpreted one based on another by giving each of them the meaning that derives from the negotiation. In case of inclarities or doubts, the special conditions would be interpreted based on the effect that it would have on the parties and not in the meaning that would have no juridicial consequence (article 683). If for one of the conditions more than one interpretation is possible than, it will be interpreted according to the normal practice in the country in which the contract is made.

If one of the parties is an enterprise, the conditions which have more than one meaning will be interpreted according to the normal procedures of the country where the headquarters of the company are located (article 684). In cases of standard contracts compiled by one of the parties, the general conditions provided by law will apply to the other party as well, only if at the moment the contract is signed, it is understood or must have been understood without any serious efforts. The expression without any serious effort must be understood not only in the fact that normal attention and concentration was paid in the study of the conditions of the contract, but also a normal level of knowledge of the conditions and the content of the contract are taken for granted. However, for this category of contracts, the conditions which are beneficial to whom has prepared the contract that result in the damage to the other party have no effect, despite cases in which this is explicitly expressed in the contract. Therefore, in the article 687 of the Albanian Civil Code is provided that "In the terminated contracts by signing modules or forms whose intention is to discipline in a uniform way the defined contractual relations, the extra conditions in these modules and forms will have priority towards the initial conditions of the modules and forms mentioned above, as long as there is a discrepancy among them even though they have not been annuled." In each case, the conditions included in the general conditions of the contract or in the modules and forms, that were stated by one of the parties, when doubts arise, are interpreted in favour of the other party (article 688). In case of doubt, the contract will be interpreted in favour of the party that has contracted the duty and always against the one that has contracted the right. When after the use of all the rules mentioned above, the content of the contract is still unclear then it will be interpreted in a way that takes into consideration the interests of both parties.

\section{Conclusions}

The rapid development of science and technology has brought as a result the establishment of a great number of form contracts that include clauses with which the responsibility of the involved parties is restricted or excluded. The imposition of the use of form contracts from big companies causes the misuse of the freedom of the signing of contracts. The typical clauses in form contracts by which the misinterpretation of the freedom of signing contracts occur are mainly the clauses about price, freedom for responsibility, exclusion from guarantee, clauses about the risk, safety, damage award etcetera. In the business world the participants in the market often break the basic rules of well-behaviour by transpassing the limits of their economic activity, with the intention of gaining a more privileged position in the market and of attracting as many clients as possible. Consequently, based on what is emphasized above, we jump to the conclusion 
that the forms presented in the market economy which are not in conformity with the principle of the contractual freedom must be considered as acts of unfair competition. This is the intention why when it comes to the defence of the interests of the consummers despite legal and juridical protection, an indispensable role must play even the interest groups.

\section{References}

The Civil Code of the Republic of Albania, approved by law No.7850, date 29.07.1994, changed by law No.8536, date 18.10.1999 and No.878, date 3.05 .2001

The Civil Code of the Popular Socialist Party of Albania, approved by law No.6340, date 26.6.1981

The Civil Code of the year 1929, Papirus, 2010

Dauti Nerxhivane, The Right of Obligations, The general and particular part, Prishtina, 2010, p.59

Dauti Nerxhivane, Some important issues related to the contractual freedom, Justitia, No.1 juridical, scientific, periodical of the Faculty of Law, 2008.

Dauti Nerxhivane, The Juridicial Nature of the Form Contracts in Economy, Prishtina, 2000, p.28

Michel Fromont Michel Fromont " The Greatest Foreign Systems of Right", Papirus, Tirana, 2009

Zweigert K. \& Kötz H., "An Introduction to Comparative Law", 3-rd edition, 1998.

From Freedom of Contract to Forcing Parties to Agreement. On the consequences of Breaking off Negotiations in different Legal Systems, 12, lus gentium, Journal of the University of Baltimore Center for International and Comparative Law 2006

Semini Mariana, The right of obligations and contracts, the general part, Scanderbeg books, Tirana 2010, p.11

Hetemi Mehdi, "The right with the basic knowledge of the commercial right, Prishtina, 1996, p.214 